\title{
Towards a typology of local migration diversity policies
}

Ilona van Breugel

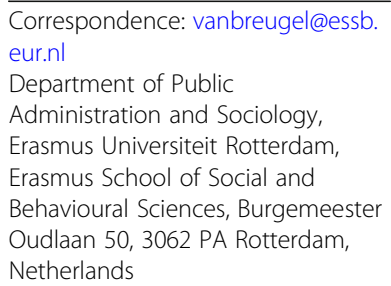

Correspondence: vanbreugel@essb. eur.nl

Department of Public

Administration and Sociology, Erasmus Universiteit Rotterdam, Erasmus School of Social and Behavioural Sciences, Burgemeester Oudlaan 50, 3062 PA Rotterdam, Netherlands

\begin{abstract}
This paper contributes to the migration studies literature by a comparative analysis of local migration diversity governance in large, mid-sized and small cities, analysing the broader scope of the local dimension of migration-diversity policies. While a 'local turn' has taken place in migration studies over the past two decades, the literature has primarily focused on capital and gateway cities. Yet immigrants arrive and settle in a much wider range of cities. Little is known about what forms migration-diversity governance across cities of different sizes and positions. This paper therefore conducts a comparative analysis of migration diversity governance across the local dimension. Based on a qualitative, comparative analysis of migration diversity policies in 16 Dutch municipalities between 2014 and 2018, I distinguish between different local migration diversity policy approaches: 'proactive pluralist', 'proactive monist', 'reactive embedded' and 'reactive one-domain'. This illustrates the variety of local approaches to migration diversity and thus argues against 'a local dimension' of migration diversity governance, rather arguing for different types of local approaches. The proactive cities explicitly chose their own framing for their migration diversity policies, in contradiction to the supposed 'paradigmatic' character of the local level, instead showing that cities position their own framing of migration diversity. The types of migration diversity policies I distinguish provide an analytical framework and starting point for further research on the variety of local migration diversity approaches.
\end{abstract}

Keywords: Local dimension, Migration diversity policies, Comparative

\section{Introduction}

In the study of immigrant and diversity governance the focus has shifted from the national to the local level, known as the 'local turn'. Local level governance is no longer considered merely a level of policy implementation but is considered an independent level of policy development (see e.g. Alexander 2003; Penninx et al. 2004; Caponio and Borkert 2010; Wimmer and Glick Schiller 2002; Zapata-Barrero et al. 2017; Caponio et al. 2018). However, studies on local migration diversity governance primarily focus on capital and gateway cities, while policy responsibilities for migration diversity have been distributed between local governments across the entire spectrum, from capital cities to smaller towns and villages, implying a variety of demographic, social and political contexts for migration policies. While some studies address migration diversity

(c) The Author(s). 2020 Open Access This article is licensed under a Creative Commons Attribution 4.0 International License, which permits use, sharing, adaptation, distribution and reproduction in any medium or format, as long as you give appropriate credit to the original author(s) and the source, provide a link to the Creative Commons licence, and indicate if changes were made. The images or other third party material in this article are included in the article's Creative Commons licence, unless indicated otherwise in a credit line to the material. If material is not included in the article's Creative Commons licence and your intended use is not permitted by statutory regulation or exceeds the permitted use, you will need to obtain permission directly from the copyright holder. To view a copy of this licence, visit http://creativecommons.org/licenses/by/4.0/. 
policy making in smaller cities, these are hardly considered in comparative local research. An analysis of different local types of migration diversity governance is thus missing.

This paper qualitatively explores the policy approaches to migration diversity across a selection of cities in the Netherlands. Based on a policy-analysis of immigrant migration diversity governance in these municipalities, the paper illustrates how migration diversity policies are developed in the decentralised context of the Netherlands building a typology of local migration diversity policies beyond the capital cities. This paper thus re-assesses the local turn by changing the focus of the research to municipalities in a variety of local settings, adding both empirically and theoretically to the understanding of local migration diversity governance. The following section starts with the theoretical framework that positions this article's contribution to the literature on local migration governance and introduces the conceptual framework that is applied for the policy analysis. After the theoretical framework, the methods for data selection, data analysis and case selection will be described. In the findings and analysis I present the four types of local migration diversity policies that I have identified. In the conclusion, finally, I reflect on the implications of these findings for the study of local migration governance.

\section{Theoretical framework}

\section{Local turn in migration studies}

Since the early 2000s the focus in migration studies shifted to the local level. Resulting in a great number of studies on local level policy making in immigration and diversity, with competing interpretations of the so-called 'local level' (Dekker et al. 2015). In line with the literature on local level policy making in other fields (O'Toole Jr 2000) some authors argue there is a convergence of local migration diversity policy making across countries, stressing the typical pragmatic problem coping character of local level policy making (Caponio and Borkert 2010; Poppelaars and Scholten 2008; Bak Jørgensen 2012). Other authors argue for 'paradigmatic pragmatism' claiming that local governments rather pragmatically combine different ideological beliefs in their diversity policies (Schiller 2015), while yet others argue that policy making at the local level is determined by its unique local political and policy context, making policy making in each, local setting different (Mahnig and Wimmer 2000; Caponio and Borkert 2010; Morales and Giugni 2011; Barbehön and Münch 2016; Martínez-Ariño et al. 2018).

Most migration diversity literature initially focused on big cities and their supposed distinctive open character (see e.g. Alexander 2003; Penninx et al. 2004; Poppelaars and Scholten 2008; Caponio and Borkert 2010; Scholten 2013). Smaller cities and towns on the other hand are considered a separate category, characterised by inter alia their relatively homogeneous demographics (Leitner 2012), consequently low intercultural competences (Glorius 2017), an overall low degree of policy activity in immigration affairs (Ramakrishnan and Wong 2010 in Filomeno 2016) and lack of ethnic networks (cp. Miksch and Schwier 2000; Schader-Stiftung 2011; Gruber 2013 in Glorius 2017). Furthermore small scale or rural cities are associated with "higher degree of social control, exclusionary practices against newcomers and .. [a strong] perception of cultural differences" (Glorius 2017, p. 117). Whereas urban, large scale cities are often associated 
with accommodation of cultural diversity, in small-scale towns it is assumed that assimilation 'into small town society' dominates (Kreichauf 2015).

The claim of capital cities as free havens of tolerance and cultural diversity, is now often disputed, instead calling attention to e.g. politics of exclusion (Ambrosini 2013) or 'scales of global salience' (Glick-Schiller and Çağlar 2009). Furthermore, a growing number of studies call to explore the broader spectrum of local migration diversity policies (Ellis 2006; Varsanyi 2008; Ramakrishnan and Wong 2010; Walker and Leitner 2011; Leitner 2012; Ambrosini and Boccagni 2015; Bonizzoni and Marzorati 2015; Kreichauf 2015; Filomeno 2016; Glorius 2017; Triviño-Salazar 2018; Desille 2018). Nevertheless, research on local migration diversity governance remains biased towards large cities. When studies do take different local contexts into account, these are studied rather separately and tend to position large and small cities in binary terms. By my knowledge little comparative research has been conducted across a variety of cities in different local settings. This paper therefore undertakes such a comparative study of the local level migration-related diversity policy making in the Netherlands. I do so by an application of Ward's (2010), see also Filomeno 2016) relational comparative approach that calls for 'studying cities through each other', without presuming fixed positions in hierarchical orders. Thus, departing from a content analysis of immigrant and diversity governance responses across different cities I inductively identify possible clusters of cities, explicitly driven by the comparative analysis of the different cases, rather than by presuming a hierarchical and scalar order between the cities (cf. Alexander 2003; Glick-Schiller and Çağlar 2009; Bell and Jayne 2009).

\section{Conceptual framework}

The key question of this paper is how local governments across a variety of local settings respond to migration related diversity. I study this through an analysis of the official policy documents on migration diversity in the selected cities. These narratives help me to reconstruct the local responses to migration diversity. I analyse the policies through a three-dimensional lens, distinguishing a problem definition, policy measures and targeting dimension. This layered lens enables me to capture an integrated picture of local diversity policies across different domains.

Policy making starts with the identification of a public problem that calls for a policy response (see e.g. Bacchi 2008). The way an issue is problematized shows the deviation between the existing and desired state of affairs (Hoppe 2011). An analysis of defined policy problems thus provides insight in the government's perception of (ideal) integration and diversity. Building on this problem dimension, how then, are policies subsequently formulated? The literature distinguishes different cultural orientations in government responses to migration diversity. In how far is migration diversity considered a permanent feature of society and how is this captured in policy measures (cf. Hammar 1985; Castles and Miller 2009 [1993]; Koopmans and Statham 2000; Alexander 2003)?

Finally, targeting sub-groups of the population is an essential element of policy making in defining government interventions and the redistribution of goods and services (Stone 1988; see also Schneider and Ingram 1993; Sen 1995; Yanow 2003; De Zwart 2005). By targeting, people are classified and categorised in policy-relevant categories (see Yanow 2003; De Zwart 2005), unveiling who the government identifies as part of, or responsible 
for the policy problem or solution, and how policies are justified (Sniderman et al. 1996). Taking these three dimension together enables me to systematically and coherently analyse (variations of) local migration-diversity policies across different domains.

\section{Methods}

This paper aims to both empirically and theoretically enhance the understanding of the local level migration-diversity policies. Given the limited number of studies on the broader local dimension of migration-diversity policies I have chosen a combination of a qualitative analysis of the policies from a relational comparative approach (Ward 2010) to identify different types of policy responses to migration-related diversity across the local dimension. This way I inductively build an analytical framework for the analysis of local migration diversity governance. Below I will discuss the approach to data selection, data analysis and case selection.

\section{Data selection - studying local migration diversity governance}

The key question of this paper is how local governments across a variety of local settings respond to migration related diversity. I study this through an analysis of the official policy documents on migration diversity in the selected cities. These official narratives help me to reconstruct the local responses to migration diversity. In the Netherlands migration diversity policies are almost completely decentralised to the local level (Van Breugel and Scholten 2019), this means local governments are responsible for integration programs and related subsidies. Furthermore, they implement anti-discrimination and antiradicalisation policies locally, as well as the housing and integration of refugees.

For each of the municipalities I have collected and subsequently selected all the official policy documents (memoranda, policy plans) on migration diversity for the Coalition Period 2014-2018 via an online city-council information system (ris or ibabs-online) and/ or the municipal website. I have selected all relevant policy documents on migration and diversity, including coalition agreements, integration or diversity memoranda and policy programs, letters from the council or relevant Alderman or Commission, policy framework, implementation plans, memos and action plans. As many cities do not (longer) have explicit migration diversity policies (see Van Breugel and Scholten 2019) the search and selection of policy documents was broadened to all policies related to migration diversity, in any policy field (see also Alexander 2003).

Based on previous research on Dutch migration diversity governance (idem) the key search terms were defined as: 'integration', 'diversity', 'anti-discrimination' and 'polarisation'. The list of search terms was expanded iteratively throughout the data search. One searchterm that was added in this process was for example 'refugee', as many municipalities developed new migration diversity policies in response to the increased arrival of asylum seekers as of $2015 .{ }^{1}$ Based on the final list of selected search terms 255 documents were collected. From this, 89 documents were selected as relevant ${ }^{2}$ and applicable to the selected timeperiod, these 89 documents were used for the analysis of this paper.

${ }^{1}$ Final list of search terms: Integratie, diversiteits-, diversiteit, diverse samenleving, inclusief, inburgering, vluchtelingen, participatieverklaring, radicalisering, extremisme, anti-discriminatie, polarisatie, statushouders, nieuwkomers, asielzoekers, AZC, arbeidsmigratie, achterstelling, jihadisme, migrant

${ }^{2}$ Filtering for 'false positives' among the search results that did not concern immigrant integration policies or the defined time period 
Policy analysis - a three dimensional lens

As mentioned above, the policies were analysed along three dimensions 'problem definition', 'policy measures' and 'target group'). The coding was done in Atlas.ti. Based on the literature I defined sensitizing categories for the coding in each of the three dimensions that enabled me to systematically and coherently analyse local migration-diversity policies via a set of categories, while inductively identifying different variations within these categories. I will explain the sensitizing categories below.

The dimension of the problem definition illustrates the governments perception on integration and diversity, as it shows how integration is perceived by the government (Bacchi 2008; Hoppe 2011). Within the problem definition dimension I distinguish between different policy domains: the socio-economic, socio-cultural, legal-political or spatial policy domain, as distinguished by inter alia Alexander (2003) and Penninx et al. (2004). Policies in the social-economic domain focus e.g. on labour market and education and refer to a structural approach to integration. Policies in the cultural religious domain relate to cultural representation, of e.g. minority (religious) groups on the one hand and more broadly speaking a public awareness of ethnic diversity in mainstream society on the other hand. Spatial policies, furthermore, relate to the spatial organisation of diversity, inter alia in relation to housing and use of place. Policies in the juridical-political domain, finally, relate to the civic status of migrants and participation and representation, and relate to integration as (political) participation (Alexander 2003; Penninx et al. 2004). During the process of coding I for example defined participation memoranda as a socio-economic integration definition, I furthermore defined anti-radicalisation policies as a category within the juridical-political domain.

Building on this problem definition I distinguish the proposed policy measures as the second dimension of my analytical framework. Through a study of the proposed policy measures the content of the policies can be determined, in particular the government's cultural orientation. In how far is migration diversity considered a permanent feature of society? How do governments perceive and address the migration diversity in their societies? Culturally monist policy measures are aimed at cultural adaptation to the host society while pluralist policy measures aim to cater cultural diversity as part of the local city identity (cf. Hammar 1985; Castles and Miller 2009 [1993]; Koopmans and Statham 2000; Alexander 2003).

Targeting finally, classifies and categorises people in policy-relevant categories (see Yanow 2003; De Zwart 2005), unveiling who the government identifies as part of, or responsible for the policy problem or solution, and how policies are justified (Sniderman et al. 1996). For the targeting dimension I distinguish between 'non-targeting'; 'universal targeting', i.e. targeting integration or diversity policies at a wider audience; and 'specific targeting', i.e. specifically addressing immigrants as target group (Schneider

Table 1 Conceptual framework

\begin{tabular}{|c|c|c|c|c|}
\hline \multirow[b]{2}{*}{ Problem definition } & \multicolumn{4}{|c|}{ Sensitizing categories } \\
\hline & Socio-economic & Juridical-political & Socio-cultural & Spatial \\
\hline Policy measures & Cultural pluralist & Cultural monist & & \\
\hline Targeting & Non-targeting & Universal targeting & Targeting migrants & \\
\hline
\end{tabular}




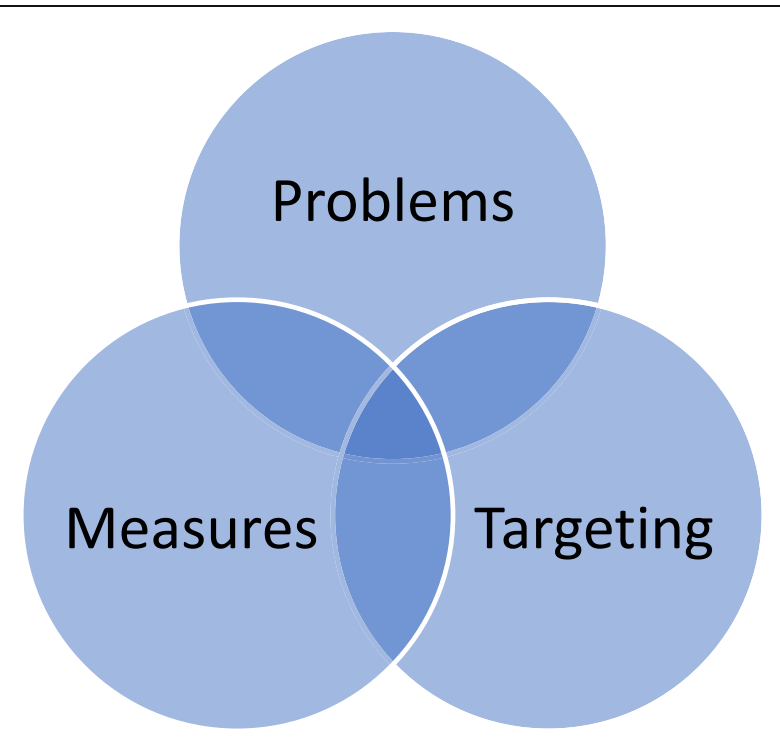

Fig. 1 Analytical lens

and Ingram 1997; De Zwart 2005; Simon and Piché 2012). During the process of coding I complemented these categories with framing strategies, such as framing policies targeted at migrants explicitly as temporary or open to other citizens too.

While models for integration create the impression of coherent sets of policies (cf. Glick-Schiller and Çağlar 2009), my proposed three-dimensional lens enables researchers to systematically and coherently analyse local migration-diversity policies, and its internal variation and contradictions that determine policy making (at the local level) (cf. Alexander 2003), facilitating an inductive clustering of different migration diversity approaches (Fig. 1 and Table 1).

In the analysis below I will identify the different problem definitions, policy measures and targeting strategies applied in the migration diversity governance in studied cities. Subsequently I will identify links between the dimensions coming to four types of local migration diversity policies.

\section{Case selection - a relation comparative lens}

This paper focuses on local integration policies in the Netherlands. Dutch migration diversity governance always has had a clear multi-level character (Scholten 2013), characterized by the interaction between the national and local level policies. In fact, the first national policies for ethnic minorities were developed in response to local policies in Rotterdam that dealt with interethnic tensions in the 'Afrikaanderwijk'-neighbourhood (Veenman 2000; Dekker and van Breugel 2019). This study takes a selection of Dutch municipalities as a starting point, working towards a typology of local migration diversity policies that can be applied and refined universally in the study of local migration diversity policies.

For this paper I have chosen to select a wide range of cases, distinguishing six different scales of city sizes by the number of inhabitants (see Table 2). From these different segments I have selected the top three municipalities (where applicable) resulting in a 
Table 2 Overview cases

\begin{tabular}{|c|c|c|c|c|c|}
\hline & Municipality & $\begin{array}{l}\text { Number of } \\
\text { inhabitants }\end{array}$ & $\#(\text { seize, } \mathrm{NI})^{\mathrm{a}}$ & $\begin{array}{l}\% \text { inhabitants with } \\
\text { migrant background }\end{array}$ & $\begin{array}{l}\text { \# (\% inhabitants with } \\
\text { migrant background) }\end{array}$ \\
\hline & & $>500.000$ & & $49,8-52 \%$ & \\
\hline 1 & Amsterdam & 833,624 & 1 & $51,7 \%$ & 2 \\
\hline 2 & Rotterdam & 629,606 & 2 & $49.80 \%$ & 3 \\
\hline \multirow[t]{2}{*}{3} & Den Haag & 519,988 & 3 & $52 \%$ & 1 \\
\hline & & $250.000-500.000$ & & $33 \%$ & \\
\hline \multirow[t]{2}{*}{4} & Utrecht & 338,967 & 4 & $33 \%$ & 10 \\
\hline & & $100.000-250.000$ & & $23-32,60 \%$ & \\
\hline 5 & Eindhoven & 224,755 & 5 & $32.60 \%$ & 12 \\
\hline 6 & Tilburg & 212,941 & 6 & $25.50 \%$ & 35 \\
\hline \multirow[t]{2}{*}{7} & Groningen & 200,952 & 7 & $23 \%$ & 58 \\
\hline & & $50.000-100.000$ & & $21,3-24,8 \%$ & \\
\hline 8 & Deventer & 98,869 & 32 & $21.30 \%$ & 69 \\
\hline 9 & Sittard-Geleen & 93,555 & 33 & $21.70 \%$ & 67 \\
\hline \multirow[t]{2}{*}{10} & Helmond & 90,127 & 34 & $24.80 \%$ & 44 \\
\hline & & $25.000-50.000$ & & $14,3-32,6 \%$ & \\
\hline 11 & Rijswijk & 49,328 & 78 & $32.60 \%$ & 13 \\
\hline 12 & Weert & 49,100 & 79 & $20.20 \%$ & 76 \\
\hline \multirow[t]{2}{*}{13} & Houten & 48,765 & 80 & $14.30 \%$ & 159 \\
\hline & & $<25.000$ & & $13,3-19,3 \%$ & \\
\hline 14 & Albrandswaard & 24985 & 219 & $19.3 \%$ & 86 \\
\hline 15 & Sliedrecht & 24968 & 220 & $13.3 \%$ & 180 \\
\hline 16 & Cuijk & 24608 & 221 & $18.8 \%$ & 91 \\
\hline
\end{tabular}

Based on data from Statistics Netherlands (CBS), accessed via CBS Statline on March 28, 2017

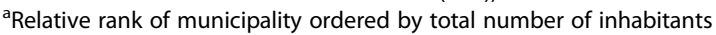

${ }^{\text {b}}$ Relative rank of municipality ordered by number of inhabitants with migrant background

selection of 16 municipalities: Amsterdam, Rotterdam, Den Haag, Utrecht, Eindhoven, Tilburg, Groningen, Deventer, Sittard-Geleen, Helmond, Rijswijk (ZH), Weert, Houten, Albrandswaard, Sliedrecht and Cuijk. The cities in the top two categories are considered 'large cities', the cities in the two middle categories 'mid-sized cities' and the cities in the two last categories 'small cities'. I apply a relational comparative perspective (Ward 2010), 'studying cities through each other', without presuming fixed positions in hierarchical orders. The division and selection of cities by scale-size is thus merely meant to serve as a tool to come to a broad selection of cities, which will later be inductively categorised based on the outcome of the policy analysis.

As a brief illustration of the variety between the cases (without presuming that these are explanatory distinctions) the cases show variety in the percentage of inhabitants with a migrant background (varying between $13.3-52 \%$ of the total city population). Furthermore, the cities are spread over the different provinces in the Netherlands (covering seven out of twelve provinces, see Table 2 and Fig. 2). ${ }^{3}$

\footnotetext{
${ }^{3}$ Covered provinces and number of cases per province: Noord-Holland (1 city); Zuid-Holland (5 cities); Utrecht (2 cities); Noord-Brabant ( 4 cities); Groningen (1 city); Overijsel (1 city); Limburg (2 cities)
} 


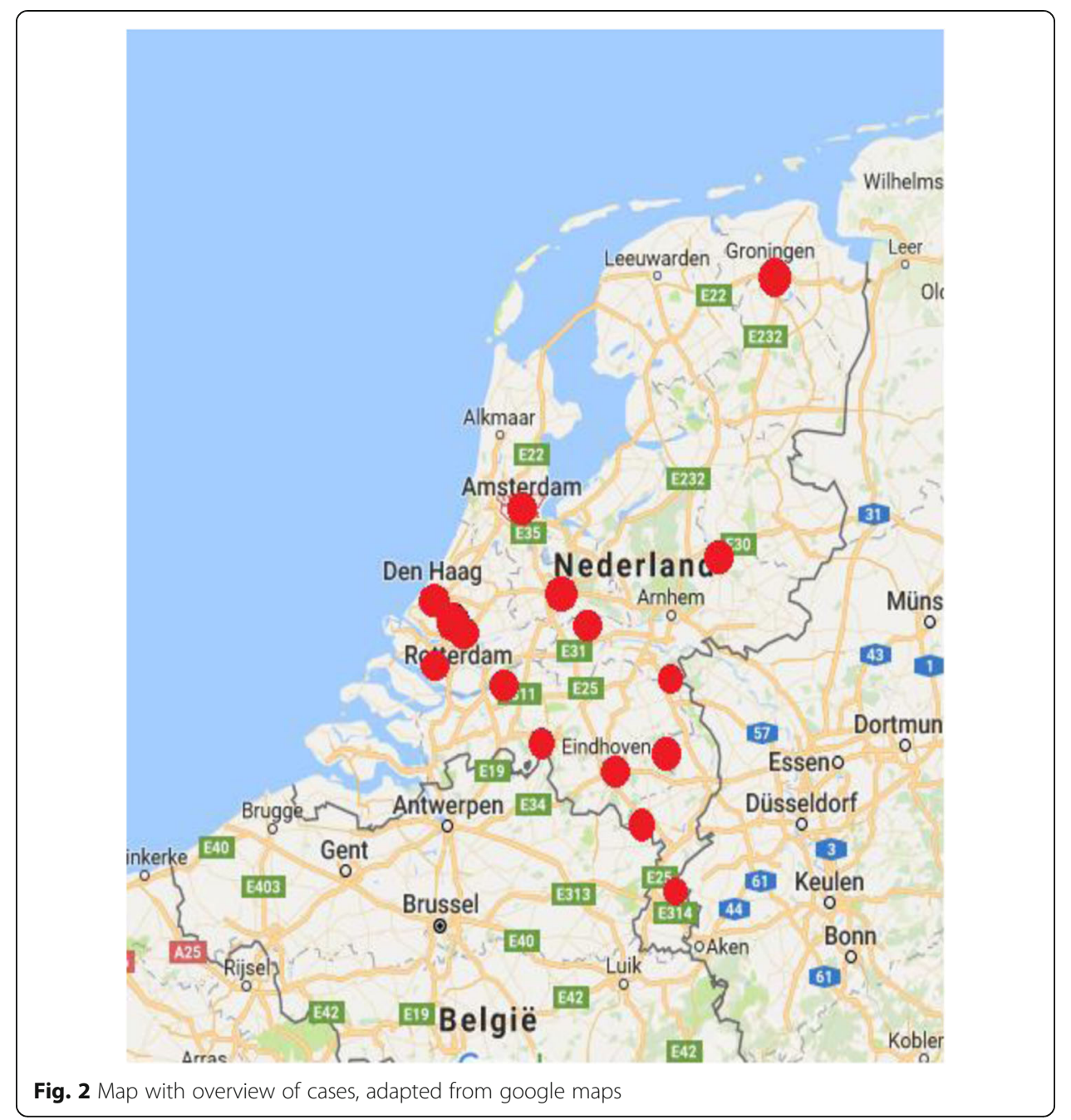

\section{Findings - four types of local migration diversity policies}

What stands out in the analysis of the local migration diversity policies is that at the start of the coalition period in 2014 only a few cities have an explicit integration or diversity agenda. Most cities do not separately address integration at all. Rather, migration diversity is addressed 'mainstreamed' (Scholten and van Breugel 2018), as part of other policy domains, such as anti-discrimination or anti-polarisation policies. In 2015 the increase in the number of refugees arriving in the Netherlands led to a demand for quick governance responses for the accommodation, housing and integration of refugees, leading to a new range of migration diversity policies in all the analysed cities. I thus differentiate two core moments of policy development. The start of the coalition period and the response to the increased refugee influx which led to the development of new local policies in all the studied cities in 2015.

In this I distinguish between cities that proactively develop these policies on their own initiative and policies that develop their policies reactively, implementing national guidelines. Different levels of embeddedness, cultural orientation and targeting strategies can be discerned. Below I will elaborate on this classification based on the 
findings of the problem definition, policy measures and targeting analysis of the of the migration diversity policies in the studied local cases.

\section{Problem definition - embedded and one-domain}

The socio-economic approach to migration diversity is most dominant across all the studied cities, with policies that portray integration as a matter of participation and self-sustainability in almost all cities. However, there are vast differences in how these are embedded across different policy domains. In Amsterdam, Rotterdam, Den Haag, Utrecht, Eindhoven, Groningen and Weert for example, integration is addressed proactively, prioritizing labour market integration in relation to a broader socio-cultural integration or diversity agenda, (also) emphasizing the accessibility and inclusiveness of the labour market and anti-discrimination programs. Tilburg, Deventer, Helmond, Rijswijk and Houten only developed these policies reactively in response to the refugee influx (policies since 2015/2016), positioning the refugee integration primarily as a socio-economic issue, concerning labour market integration and educational participation. The policies are considered to be of temporary nature, aimed at rapid integration in generic facilities and striving for self-sustainability.

In the juridical-political domain too, a distinction can be made between one-domain and embedded policy approaches. This concerns primarily anti-radicalisation policies. A distinction can be made between municipalities that problematize radicalisation stricly as a safety issue (Deventer and Sittard-Geleen) and broader defintions that link radicalisation to segregation and polarization in society. The latter focus on prevention as well as repression, through dialogue and resilience training programs (Amsterdam, Rotterdam, Den Haag, Utrecht, Tilburg, Groningen, Helmond, Rijswijk and Weert). An example of the latter is Utrecht's anti-segregation program, a tiered approach that focus on connecting people, early signalling, guiding and where necessary repression. The approach explicitly connects antiradicalisation to a broader approach combatting segregation and polarisation as a breeding ground for radicalisation, and thereby focus on segregation as an issue for the entire city.

In the spatial domain too different levels of embeddedness can be distinguished. This concerns policies on (spatial-)segregation and the composition of neighbourhoods (Rotterdam and Utrecht). As of 2016 spatial policies furthermore came to focus on the housing of asylum seekers. Based on a national target, municipalities get assigned a number of refugees that they need to house in their municipality. These range from mere accommodation (Albrandswaard), to more embedded approaches linking the housing assignment to integration and broader support structures (Rotterdam, Den Haag, Utrecht, Tilburg, Groningen, Deventer, Helmond and Houten). Furthermore in Rotterdam, Den Haag and Utrecht the municipality explicitly calls for dispersal policies or 'mixed housing' to avoid segregation (Rotterdam, Den Haag and Utrecht). Except for Rotterdam and Utrecht spatial policies are only addressed reactively in relation to refugee policies.

In contrast to the political and public debate, the cultural-religious domain is the least addressed of all. Den Haag, Groningen and Weert have an explicit 'diversity' agenda, Utrecht has a very elaborate anti-radicalisation approach, focusing explicitly on diversity in the city too. Utrecht, Groningen and Weert focus on cultural diversity as a value and an asset to the city, explicitly making diversity (migration diversity along with other forms as diversity such as sexual diversity) an issue of the entire city. Rotterdam and Den Haag take 
a much more cautious approach. While acknowledging the diverse make-up of the city their they 'problematize' this very different. Den Haag has a two-fold approach, while it does emphasize that it strives to be an open city in which everyone can feel at home, together with Rotterdam it also focuses on adaptation to shared norms and values.

Based on the above Albrandswaard and Sittard-Geleen can be distinguished as cities with a limited approach to migration diversity, as they are the only cities in which integration is only addressed in one domain. After that follow the cities that although approaching integration broader, do so from one specific angle, making this the priority of the city. For example, in Amsterdam diversity as such is not explicitly addressed at all, rather all policies are built around a framework of human rights. Eindhoven on the other hand explicitly positions itself with an approach focused on participation, with a broad anti-discrimination strategy. In a similar vein Tilburg, Helmond and Rijswijk focus on (an embedded) anti-radicalisation approach. The most elaborate and embedded integration approached are found in Rotterdam, Den Haag, Utrecht, Groningen, Weert. Of these cities Groningen, Weert and Utrecht focus on diversity most explicitly. This illustrates how cities take different positions in their migration diversity approaches, either proactively with an explicit diversity agenda, or reactively, developing embedded or one-domain programs combating polarisation or facilitating the housing of refugees. While the larger and mid-sized cities tend to have more extensive migration diversity programs, their respective positioning differs. Below I will look at the policy measures the cities adopt to explore these positions further.

\section{Policy measures - monist and pluralist}

For the analysis of the policy measures I have assessed whether the proposed policy measures were targeted at cultural monism or pluralism. Cultural pluralist policies are present in Den Haag, Eindhoven, Tilburg, Deventer, Helmond, Rijswijk, but most explicitly in Utrecht, Groningen and Weert. The policies can be recognized by an explicit orientation on all citizens, as seen with inclusive citizenship approaches in Utrecht, Groningen and Weert; the accessibility of generic policies and institutes, or diversity awareness of generic institutions, as seen in Den Haag, Eindhoven, Tilburg, Groningen, Deventer and Weert, and finally the broad embedding of specific programs like antiradicalization or refugee integration programs. Measures focused on cultural monism focus on cultural adaptation and can be recognised in Amsterdam, Rotterdam, Den Hague, Utrecht, Deventer, Rijswijk and Houten. In Amsterdam for example citizens with a 'non-Western' background are explicitly targeted for the 'pink agenda' and the 'women-emancipation' memorandum.

In the previous section I distinguished between proactive and reactive policies. Here I refine this distinction by looking at the content of those policies. What stands out from the analysis is that most cities only address migration diversity indirectly. As described in the previous section policies are rather framed in socio-economic terms. A small number of the cities does not address migration diversity at all, unless required by implementation of national guidelines on for example refugee housing. While the reactive cities tend to less explicitly address the cultural dimension of migration diversity, the proactive cities can be split up in culturally monist and pluralist. 


\section{Target groups - direct and indirect}

Finally, I have looked at the target groups that are defined in the policy measures. First of all, in line with the earlier observed trend of implicit references to migration diversity, a trend of generic, non-targeted, policies is clearly visible across the cities. In many cities a broader audience is targeted for migration diversity or social inclusion policies. On the one hand there is a group of cities that aims to inclusively address all its citizens via an explicit diversity (Den Haag, Groningen, Weert) or participation agenda, addressing the entire city (Rotterdam, Eindhoven), or a broadly embedded antiradicalisation approach (Utrecht, Helmond, Rijswijk). In Den Haag all citizens that 'withdraw' from society are explicitly targeted, but 'Hagenaars' who do not feel comfortable with the diversity in the city are targeted too. On the other hand there are a few cities that have explicitly denounced group-based policies altogether (Amsterdam and Weert). While in Weert the former targeted integration policies are replaced by an inclusive diversity agenda, Amsterdam has reshaped its entire agenda around a human rights frame, explicitly denouncing group-based policies for citizens with a migration background. Nevertheless in both cities targeted policies are applied in certain subdomains, such a refugee integration policies and (lgtbi) emancipation programs. In Cuijk no targeted migration diversity policies were observed at all.

Secondly, despite the emphasis on generic framing, most cities combine generic and targeted policies. In combing generic and targeted policies, different framing strategies can be distinguished, such as framing targeted policies as temporary, or open to other target groups too. Both forms of framing primarily occur around the housing and integration programs that were set up for refugees as of 2015. Several cities emphasize that the integration programs they set-up for refugees are of a temporary nature only, aimed at the eventual self-sustainability of the refugees (Rotterdam, Den Haag, Utrecht, Tilburg, Deventer, Helmond, Houten, Albrandswaard). The temporary-framing frequently coincides with a combined targeting of migrant and non-migrants groups. In Tilburg and Houten for example policies focus on increasing the accessibility of the facilities for all citizens and (thereby) increasing the public support for inter alia refugee integration measures. The cities emphasize the accessibility of these facilities for nonimmigrant citizens or emphasizing the need to maintain public support for these measures (Rotterdam, Den-Haag, Utrecht, Tilburg, Deventer and Houten). This can also be observed in EU labour-migrant policies in Rotterdam which mention the importance of 'creating a level-playing field' for the Rotterdam workforce. Also with refugee housing policies, several municipalities connect this to a wider target group by drawing attention to the pressure on the housing market (Rotterdam, Utrecht, Tilburg, Helmond and Houten), again linking migration diversity measures to public support.

Finally, targeted policies appear in an interesting set of cities. In contrasted to the broad approaches described above, in Houten and Albrandswaard refugee integration policies are targeted at refugees only. In Sliedrecht 'allochtonous' youngsters are targeted for sports programs, while Rotterdam and Den Haag have policies specifically targeted at citizens with a Moroccan, Antillean and Turkish background and EU labour migrants. Non-Western youngsters, girls and 'isolated women' are targeted within generic participation and emancipation programs (Amsterdam, Rotterdam).

Based on the analysis above a distinction can be made between direct and indirect forms of targeting. An emphasis on generic targeting is dominant across a large 
share of cities. Despite this generic framing in many cities targeted policies coexist, though these are framed as temporary or explicitly target non-migrant groups too. In line with the observed trend of policy measures only indirectly addressing migration diversity, targeting too occurs directly and indirectly. The 'proactive pluralist' cities tend to explicitly target directly and inclusively, while both 'proactive monist' and 'reactive embedded' target indirectly through the temporary and combined framing. The 'reactive one-domain' cities finally also target directly, however only in a few separate policies.

\section{Analysis}

First, I will reiterate some of the trends in migration-diversity strategies that can be recognised across the different cities and discuss how trends across the different dimensions interact. Secondly, I will discuss policy characteristics of clusters of cities identify different city types.

A first thing that becomes apparent across the cases is the focus on generic or mainstreamed policies. Most municipalities have departed from explicit integration policies, rather addressing migration diversity indirectly, as part of other policies and across different policy domains. This can be observed in indirect forms of targeting too. However how these policies are embedded differs between the cities, varying between participation programs, diversity agendas and refugee integration programs. In the policy period under study two core policy moments stand out. The beginning of the coalition period in which a small selection of the cities phrased explicit migration diversity programs, and the increased refugee influx in 2015 in response to which all cities later developed migration diversity policies for refugee integration.

Based on an analysis of the problem definition, policy measures and target groups of local migration diversity policies I have inductively identified four types of local migration diversity policies. I distinguish between cities that proactively and independently developed migration diversity policies at the start of the coalition period, such as a diversity agenda, and the cities that formed these reactively, in response to the refugee crisis or other national guidelines on for example anti-discrimination or antiradicalisation. The policies in the 'proactive cities' are typically developed as embedded approaches, cutting across different policy domains, such as programs linked to an embedded diversity agenda or anti-polarisation approach. Although these cities fall apart in a cluster of cities with policy measures aimed at cultural adaptation (cultural monism) and a cluster of cities that explicitly target cultural plurality.

The cities that developed their policies reactively on the other hand do not explicit address their cultural orientation, rather these cities can be distinguished by an embedded and one-domain approach. Such as policy responses limited to the housing of refugees, or more holistic and integrated refugee integration approaches, where housing and integration policies are linked to a broader program on self-sustainability, in the domain of education and the labour market. The 'reactive embedded' and 'proactive monist' cities both apply indirect forms of targeting, such as targeted approaches that are framed as temporary, or combining different target groups to broaden the public support for these measures. 'Proactive pluralist' and 'reactive one-dimension' cities both target directly, although addressing different target groups (Table 3). 
Table 3 City types

\begin{tabular}{|c|c|c|c|}
\hline Proactive pluralist & Proactive monist & Reactive embedded & $\begin{array}{l}\text { Reactive one- } \\
\text { domain }\end{array}$ \\
\hline Proactive & & Reactive & \\
\hline Embedded & & Embedded & One domain \\
\hline Cultural pluralism & Cultural monism & - & \\
\hline Direct targeting & Indirect targeting & & Direct targeting \\
\hline $\begin{array}{l}\text { Utrecht, Groningen and } \\
\text { Weert }\end{array}$ & $\begin{array}{l}\text { Rotterdam and Den } \\
\text { Haag }\end{array}$ & $\begin{array}{l}\text { Amsterdam, Eindhoven, } \\
\text { Tilburg, } \\
\text { Deventer, Helmond } \\
\text { Rijswijk and Houten }\end{array}$ & $\begin{array}{l}\text { Sittard-Geleen, } \\
\text { Albrandswaard, } \\
\text { Sliedrecht and Cuijk }\end{array}$ \\
\hline
\end{tabular}

The first cluster of 'proactive pluralist' cities consists of the large, mid-sized and small cities Utrecht, Groningen and Weert, with proactive diversity policies, embedded across different policy domains and an explicit orientation on cultural diversity, such as the Groningen diversity agenda. The second cluster of 'proactive monist' cities consists of the two large cities Rotterdam and Den Haag, also characterised with a proactive diversity approach that is embedded over different policy domains. This cluster of cities however, is defined rather by a cultural monist orientation, with a focus on cultural adaptation such as the Rotterdam integration memorandum. Policies operate by a mix of generic and targeted policies, however the most remarkable trend in this regard is the use of indirectly targeted policies, framed temporary or combined targeting.

The third cluster of 'reactive embedded' cities consists of the mid-sized and small cities Eindhoven, Tilburg, Deventer, Helmond, Rijswijk and Houten, that form a set of reactive policies, that are nevertheless embedded across different policy domains. Like the equal opportunities approach in Eindhoven or the broad anti-polarisation approach in Tilburg. Like the 'proactive monist' cities the policies are characterised by targeted measures that are temporary and explicitly targeting non-migrant groups too. The last cluster of 'reactive, one-domain' cities consists of the mid-sized city Sittard-Geleen, and the small cities Albrandswaard, Sliedrecht and Cuijk, who are defined by reactive and one-domain approaches to integration, typically by targeted policies, such as the refugee housing policies in Albrandswaard or sport policies for children with a migration background in Sliedrecht.

The analysis shows the variety between cities in their local migration diversity policies, and the different policy moments they seize formulate these policies. While there is a rough distinction between the larger cities with proactive policies, and smaller cities that tend to develop their policies reactively, the large-small city variation does not explain borderline cases and outliers like capital city Amsterdam as reactive, or the midsized and small cities of Groningen and Weert as proactive. Furthermore, when looking at the clusters within the proactive migration diversity policies, the cluster of large, mid-sized and small cities of Utrecht, Groningen and Weert are characterised by their cultural pluralist approach while the larger cities Rotterdam and Den Haag classify as cultural monist. The larger cities seem to have moved away from (former) accommodative policies, by explicitly denouncing this former pluralist approach (Rotterdam) or replacing migration diversity altogether for a human rights framework (Amsterdam), perhaps having reached a different policy phase (cf. Alexander 2003). However, further 
research is necessary to explain the cluster of large, mid-sized and small cities that adopted a proactive pluralist approach.

\section{Conclusion}

Based on an analysis of the problem definition, policy measures and target groups of local migration diversity policies I have inductively identified four types of local migration diversity policies: 'proactive pluralist', 'proactive monist', 'reactive embedded' and 'reactive one-domain'. This illustrates the variety of local migration-diversity policies, and thus argues against a 'local dimension' of migration diversity policies (Caponio and Borkert 2010; Poppelaars and Scholten 2008; Bak Jørgensen 2012), rather illustrating the variety of local approaches. This study also invalidates the claim of the 'pragmatic' local level (Caponio and Borkert 2010; Poppelaars and Scholten 2008; Bak Jørgensen 2012), as it shows that that cities position their own framing of migration diversity.

This emphasizes the importance of taking the full local dimension into account when studying local level migration diversity governance. The different clusters of cities show that we need to move beyond binary division between large and small cities to understand local migration policy making. My findings reject the claim that larger cities would be more open and accommodating to migration than smaller cities (see e.g. Alexander 2003; Penninx et al. 2004; Poppelaars and Scholten 2008; Caponio and Borkert 2010; Scholten 2013). Further in-depth research on the respective policy types is necessary to explain the different clusters of large, mid-sized and small cities across the policy.

The three-dimensional lens to study migration diversity, as applied in this paper, enables a systematic and coherent analysis of local migration diversity policies across different domains. It enables researchers to 'study cities through each other' as proposed in Ward's relational comparative approach Ward (2010), equipping an inductive clustering of different multi-layered migration diversity approaches that move beyond integration models. The types of migration diversity policies I distinguish here provide an analytical framework and starting point for further research on the variety of local migration diversity approaches.

Acknowledgements

The author would like to thank Sevgi Yilmaz for her assistance in analysing the data for this study. Furthermore she would like to thank the anonymous reviewers, Angelique van Dam, Charlotte Räuchle, Juan Carlos Triviño-Salazar, Antonie Schmiz, Amandine Desille and Maria Schiller for their helpful comments on earlier versions of this paper.

Author's contributions

The author(s) read and approved the final manuscript.

Author's information

Ilona van Breugel is a post-doctoral researcher at the department of Public Administration and Sociology at the Erasmus University Rotterdam. Her research focuses on (local) governance of migration diversity

Funding

Not applicable. The research was conducted as part of a PhD appointment, no second or third stream funding was used for this research.

Availability of data and materials

The datasets used and/or analysed during the current study are available from the corresponding author on reasonable request. 
Received: 9 August 2019 Accepted: 2 April 2020

Published online: 03 July 2020

\section{References}

Alexander, M. (2003). Local policies toward migrants as an expression of host-stranger relations: a proposed typology. Journal of Ethnic and Migration Studies, 29(3), 411-430

Ambrosini, M. (2013). 'We are against a multi-ethnic society': policies of exclusion at the urban level in Italy. Ethnic and Racial Studies, 36(1), 136-155.

Ambrosini, M., \& Boccagni, P. (2015). Urban multiculturalism beyond the 'backlash': new discourses and different practices in immigrant policies across European cities. Journal of Intercultural Studies, 36(1), 35-53.

Bacchi, C. (2008). Women, policy and politics. The construction of policy problems. Los Angeles: Sage Publications.

Bak Jørgensen, M. (2012). The diverging logics of integration policy making at national and city level. International Migration Review, 46(1), 244-278.

Barbehön, B., \& Münch, S. (2016). The 'distinctiveness of cities' and distinctions in cities: boundaries of belonging in comparative perspective. Urban Research \& Practice, 9(1), 37-55. https://doi.org/10.1080/17535069.2015.1037342.

Bell, D., \& Jayne, M. (2009). Small cities? Towards a research agenda. International Journal of Urban and Regional Research, 33(3), 683-699.

Bonizzoni, P., \& Marzorati, R. (2015). Local immigrant incorporation pathways in small-scale cities. Pakistani immigrants in a province of northern Italy. Sociologica, 9(2).

Caponio, T., \& Borkert, M. (2010). Introduction. In T. Caponio, \& M. Borkert (Eds.), The local dimension of migration policymaking (pp. 9-32). Amsterdam: Amsterdam University Press.

Caponio, T., Scholten, P., \& Zapata-Barrero, R. (Eds.) (2018). The Routledge handbook of the governance of migration and diversity in cities. London and New York: Routledge.

Castles, S., \& Miller, M. J. (2009). The age of migration: international population movements in the modern world. Macmillan International Higher Education.

De Zwart, F. (2005). The dilemma of recognition: administrative categories and cultural diversity. Theory and Society, 34(2), 137-169.

Dekker, R., Emilsson, E., Krieger, B., \& Scholten, P. (2015). A local dimension of integration policies? A comparative study of Berlin, Malmo and Rotterdam. International Migration Review, 49(3), 633-658.

Dekker, R., \& Van Breugel, I. (2019). 'Walking the Walk' rather than 'Talking the Talk' of superdiversity: continuity and change in the development of Rotterdam's immigrant integration iolicies. In Scholten, P., Crul, M. and van de Laar, P. (Eds.), Coming to Terms with Superdiversity (pp. 107-132). Cham: Springer.

Desille, A. (2018). From national to municipal? Local perspectives on integration policies in Israel. Espaces et Sociétés, $172-$ 173(1), 93-108.

Ellis, M. (2006). Unsettling immigrant geographies: US immigration and the politics of scale. Tijdschrift Voor Economische en Sociale Geografie, 97(1), 49-58.

Filomeno, F. A. (2016). Theories of local immigration policy. Cham: Springer.

Glick-Schiller, N. G., \& Çağlar, A. (2009). Towards a comparative theory of locality in migration studies: migrant incorporation and city scale. Journal of Ethnic and Migration Studies, 35(2), 177-202.

Glorius, B. (2017). The challenge of diversity in rural regions: refugee reception in the German Federal State of Saxony. Hungarian Geographical Bulletin, 66(2), 113-128.

Hammar, T. (Ed.) (1985). European immigration policy: a comparative study. Cambridge: Cambridge University Press.

Hoppe, R. (2011). The governance of problems: puzzling, powering and participation. Bristol: Policy Press.

Koopmans, R., \& Statham, P. (Eds.) (2000). Challenging immigration and ethnic relations politics: comparative European perspectives. Oxford: Oxford University Press.

Kreichauf, R. (2015). Ghettos in small towns? The research on ethnic segregation and stigmatisation processes in small town Germany. Sociologica, 9(2).

Leitner, H. (2012). Spaces of encounters: immigration, race, class, and the politics of belonging in small-town America. Annals of the Association of American Geographers, 102(4), 828-846.

Mahnig, H., \& Wimmer, A. (2000). Country-specific or convergent? A typology of immigrant policies in Western Europe. Journal of International Migration and Integration/Revue de l'integration et de la migration internationale, 1(2), 177-204.

Martínez-Ariño, J., Moutselos, M., Schönwälder, K., Jacobs, C., Schiller, M., \& Tandé, A. (2018). Why do some cities adopt more diversity policies than others? A study in France and Germany. Comparative European Politics, 17, 651-672. https://doi. org/10.1057/s41295-018-0119-0.

Miksch, J., \& Schwier, A. (2000). Fremde auf dem Lande [Strangers in the country]. Frankfurt/Main: Otto Lembeck Verlag.

Morales, L., \& Giugni, M. (Eds.) (2011). Multicultural democracy and immigrants' social capital in Europe. Houndmills: Palgrave.

O'Toole Jr., L. J. (2000). Research on policy implementation: assessment and prospects. Journal of Public Administration Research and Theory, 10(2), 263-288.

Penninx, R., Kraal, K., Martiniello, M., \& Vertovec, S. (2004). Introduction: European cities and their new residents. In R. Penninx, K. Kraal, M. Martiniello, \& S. Vertovec (Eds.), Citizenship in European Cities. Immigrants, Local Politics and Integration Policies (pp. 3-17). Farnham: Ashgate publishing.

Poppelaars, C., \& Scholten, P. (2008). Two worlds apart. The divergence of national and local immigrant integration policies in the Netherlands. Administration and Society, 40(4), 335-357.

Ramakrishnan, S. K., \& Wong, T. (2010). Partisanship, not Spanish: explaining municipal ordinances affecting undocumented immigrants. In M. Varsanyi (Ed.), Taking local control: immigration policy activism in US cities and states (pp. 73-93). Stanford: Stanford University Press.

Schiller, M. (2015). Paradigmatic pragmatism and the politics of diversity. Ethnic and Racial Studies, 38(7), 1120-1136.

Schneider, A., \& Ingram, H. (1993). Social construction of target populations: implications for politics and policy. American Political Science Review, 87(2), 334-347.

Schneider, A., \& Ingram, H. (1997). Policy design for democracy. Lawrence: University Press of Kansas.

Scholten, P. (2013). Agenda dynamics and the multi-level governance of migrant integration. The case of Dutch migrant integration policies. Policy Sciences, 46, 217-236. 
Scholten, P. and van Breugel, I. (Eds.) (2018) Mainstreaming integration governance. New trends in migrant integration policies in Europe. Cham: Palgrave Macmillan.

Sen, A. (1995). The political economy of targeting. In D. Van de Walle, \& K. Neads (Eds.), Public spending and the poor, Baltimore and London. Baltimore: Johns Hopkins University Press.

Simon, P., \& Piché, V. (2012). Accounting for ethnic and racial diversity: the challenge of enumeration. Ethnic and Racial Studies, 35(8), 1357-1365.

Sniderman, P. M., Carmines, E. G., Layman, G. C., \& Carter, M. (1996). Beyond race: social justice as a race neutral ideal. American Journal of Political Science, 40(1), 33.

Stiftung, S. (2011). Integrationspotenziale in kleinen Städten und Landkreisen [Integration potential in small towns and counties]. Ergebnisse des Forschungs-Praxis-Projekts Darmstadt.

Stone, D. A. (1988). Policy paradox and political reason. New York: WW Norton \& Company.

Triviño-Salazar, J. C. (2018). The politics of immigration locally: alliances between political parties and immigrant organizations. Ethnic and Racial Studies, 41(9), 1728-1746.

Van Breugel, I., \& Scholten, P. (2019). Governance by proxy: a comparative policy analysis of the mainstreaming of immigrant integration governance. Journal of Comparative Policy Analysis: Research and Practice, 22(3), 207-225. https://doi.org/10. 1080/13876988.2019.1619973.

Varsanyi, M. W. (2008). Rescaling the "alien," rescaling personhood: neoliberalism, immigration, and the state. Annals of the Association of American Geographers, 98(4), 877-896.

Veenman (2000). Changing policies on immigrants in Rotterdam. Rotterdam: Erasmus Universiteit Rotterdam.

Walker, K. E., \& Leitner, H. (2011). The variegated landscape of local immigration policies in the United States. Urban Geography, 32(2), 156-178.

Ward, K. (2010). Towards a relational comparative approach to the study of cities. Progress in Human Geography, 34(4), $471-487$.

Wimmer, A., \& Glick Schiller, N. (2002). Methodological nationalism and beyond: nation-state building, migration and the social sciences. Global Networks, 2(4), 301-334.

Yanow, D. (2003). Constructing race and ethnicity in America: Category-making in public policy and administration. London: Routledge.

Zapata-Barrero, R., Caponio, T., \& Scholten, P. (2017). Symposium on theorizing 'the local turn' in the governance of immigrant policies: a multi-level approach. International Review of Administrative Sciences, 83(2).

\section{Publisher's Note}

Springer Nature remains neutral with regard to jurisdictional claims in published maps and institutional affiliations.

\section{Submit your manuscript to a SpringerOpen ${ }^{\circ}$ journal and benefit from:}

- Convenient online submission

- Rigorous peer review

- Open access: articles freely available online

- High visibility within the field

- Retaining the copyright to your article

Submit your next manuscript at $\boldsymbol{\nabla}$ springeropen.com 